\title{
Knowledge, Attitudes and Contraceptive Practices among Young People from the Youth Listening Center of the Burkinabè's Family Well-Being Association in Bobo-Dioulasso City
}

\author{
Der Adolphe Somé1, Yaméogo Rélwendé Barnabé1, Kaboré Ahmed ${ }^{2}$, Ouattara Souleymane1, \\ Obossou Awade Afoukou Achille ${ }^{3}$, Thieba Bonane Blandine ${ }^{4}$, Dao Blami ${ }^{5}$
}

\footnotetext{
${ }^{1}$ Department of Gynecology Obstetrics and Reproductive Medicine, Souro Sanou University Teaching Hospital, Bobo-Dioulasso, Burkina Faso

${ }^{2}$ Department of Public Health, Joseph KI Zerbo University, Ouagadougou, Burkina Faso

${ }^{3}$ Department of Gynecology and Obstetrics, University Teaching Hospital of Parakou, Parakou, Benin

${ }^{4}$ Department of Gynecology and Obstetrics, Yalgado Ouédraogo University Teaching Hospital, Ouagadougou, Burkina Faso ${ }^{5}$ Jhpiego, Ouagadougou, Burkina Faso

Email: adolphesomeder@yahoo.fr
}

\begin{abstract}
How to cite this paper: Somé, D.A., Barnabé, Y.R., Ahmed, K., Souleymane, O., Achille, O.A.A., Blandine, T.B. and Blami, D. (2019) Knowledge, Attitudes and Contraceptive Practices among Young People from the Youth Listening Center of the Burkinabè's Family Well-Being Association in Bobo-Dioulasso City. Open Journal of Obstetrics and Gynecology, 9, 1315-1324. https://doi.org/10.4236/ojog.2019.910127
\end{abstract}

Received: September 1, 2019

Accepted: September 26, 2019

Published: September 29, 2019

Copyright (๑) 2019 by author(s) and Scientific Research Publishing Inc. This work is licensed under the Creative Commons Attribution International License (CC BY 4.0).

http://creativecommons.org/licenses/by/4.0/

\section{c) (i) Open Access}

\begin{abstract}
Objective: To study the knowledge, attitudes and practices regarding contraception among young people in the Burkinabè's family well-being association for youth listening center in Bobo-Dioulasso city. Methods: This was a survey of 635 clients in the youth listening's center of Bobo-Dioulasso city, Burkina Faso. These clients were gradually included by random choice from January 15 to April 15, 2018. The data were collected by self-administered written questionnaire under the supervision of an investigator and after a free and informed verbal agreement of the participant. The analysis was done using the software Epi info version 7.1.1.0. Results: The average age of the respondents was 20.62 years. Female respondents were more numerous, 508 (80\%). Contraceptive methods were known by $98.12 \%$ of respondents and $61.42 \%$ said they were always using them. Two-thirds of clients (67\%) cited at least two benefits of contraceptive methods which were correct. Condoms were the best-known method (92.60\%) and also the most used (92.56\%). But emergency contraception was known by $30.71 \%$ of participants. Young people who were already sexually active accounted for $73.54 \%$ of the sample with a mean age at their first sexual intercourse of 18.42 years. Conclusion: The majority of respondents knew contraceptive methods. However, risky sexual behaviors and misconceptions about contraception remain. The setting up of family planning services within schools and the teaching of a reproductive
\end{abstract}


health module in all secondary schools will contribute to improve their sexual and reproductive health.

\section{Keywords}

Contraception, Sexuality, Young, Bobo-Dioulasso

\section{Introduction}

The use of family planning has increased significantly in many parts of the world, but Africa has one of the highest fertility rates and the fastest population growth in the world [1]. Since the Cairo International Conference on Population and Development (ICPD) in 1994, the adolescents' access to reproductive health services has entered into international agendas.

According to a school-based study in Guinea, 59.3\% of young people were sexually active. Of these, $49.3 \%$ had early sex, $17.1 \%$ had more than one sexual partner in the past 12 months and $39.8 \%$ had more than one sexual partner at the same time [2].

In Burkina Faso, youth's health has since occupied an important place in population policy. Many actions are undertaken, such as the campaigns of awareness, promotion of contraceptive products and the setup of listening centers for young people. Despite of these efforts, this target group still faces sexual and reproductive health problems. A study conducted in schools in Ouagadougou (Nacanabo, 2007) showed that $97.4 \%$ of students had knowledge about contraceptive methods and $30.8 \%$ were using them [3]. In terms of sexuality, contraception and sexually transmitted infections, young people are still a vulnerable population in Burkina Faso. However, activities in youth listening are centers concern especially sexual and reproductive health education. The fight against unwanted pregnancies and sexually transmitted infections is one of the priorities of these centers through the promotion of contraception. Most of the young people who attend these centers have a minimum of knowledge about contraception. This study aimed to evaluate knowledge, attitudes and practices of the youth listening center of the Burkinabè's family well-being association in Bobo-Dioulasso city.

\section{Materials and Method}

\subsection{Framework and Scope of the Study}

Youth listening center of the Burkinabè's family well-being association in Bobo-Dioulasso city served as a framework for our study. A young people's attending center appeared to be the better place to achieve the objectives.

\subsection{Type, Period of Study and Participants}

It was a prospective cross-sectional study from January 15th to April 15th, 2018. 
The source population was all young people using this center services.

Inclusion Criteria: Those who were included in the study were all young met at the center during the period of investigation and who accepted freely to be interviewed.

Non-inclusion criteria: were not surveyed, trainees and any other non-permanent health worker in the services concerned at the time of the study

\subsection{Sample and Sampling}

A total of 635 young people were included. It was an accidental inclusion during the period of investigation aiming all young responding to inclusion criteria.

\subsection{Data Collection}

The data were collected during a self-administered written questionnaire under the supervision of an investigator. The variables studied were related to young's socio-demographic characteristics, their Knowledge, attitude and practices about contraception as well as reasons for non-use of contraceptive methods and their prospects for contraceptive use. Two midwives trained in collection techniques and the rules of ethics and confidentiality collected data during the working days. Before the beginning of data collection, a pretest was conducted in a similar youth center in Banfora city, Burkina Faso.

\subsection{Data Treatment and Analysis}

Data were analyzed using the software Epi info version 7.1.1.0.

\subsection{Ethical Considerations}

An authorization from the regional director of health, as well as the administrative authorization from the direction this youth health center were obtained first. All participants in the study gave a free and informed verbal and enlightened agreement to take part in the survey. The anonymity and confidentiality of the content of the questionnaires were ensured throughout the study.

\section{Results}

\subsection{Socio-Demographic Characteristics}

The average age of the respondents was 20.60 years \pm 3.60 years with extremes of 11 and 34 years. The age group of 20 to 24 years accounted for $42.68 \%$. The female respondents were $508(80 \%)$ and the male were 127 (20\%). Then the sex ratio was 0.25 .

Respondents who we educated up to secondary level accounted for $75.28 \%$, those who had reached university level, $22.99 \%$ and $1.73 \%$ of them never went school.

Participants who were singles accounted for $89.45 \%$ of respondents and married $7.40 \%$.

As for their religious affiliation, $58.11 \%$ declared practicing the Muslim religion, $41.57 \%$ that of Christianity and $0.31 \%$ animism. 


\subsection{Sexual Behavior of Young People}

At the time of the survey, 467 respondents (73.54\%) declared that they have already got experience in sex relation. These sexual relations were regularly conducted according to $44.75 \%$ of respondents. During coitus, $7.49 \%$ of young people said they never protected themselves, compared to $37.26 \%$ of them who said they always protected themselves. Also, more than half of young people (55.25\%) declared protecting themselves sometimes.

A total of 467 respondent sprecised the age they had when they got their first sex. The mean age at first experience of sex was 18.42 years with extremes of 10 and 29 years. It was 16.72 years for girls and 17.54 years for boys. The distribution of respondents by age at first experience of sex is shown in Table 1.

\subsection{Knowledge of Respondents about Contraception}

\section{- Knowledge on contraceptive methods}

Respondents who admitted they knew contraceptive methods accounted for 98.12\%. The methods known are reported in Figure 1 bellow.

\section{- Sources of information about contraceptive methods}

The persons surveyed were informed about contraceptive methods, firstly at school (65.35\%), secondly by peers (17.32\%) and finally at health centers $(9.92 \%)$.

- Knowledge about advantages and disadvantages of contraceptive methods

Regarding the benefits (Table 2) and disadvantages (Table 3) of contraceptive methods, respectively 554 out of 635 (87.24\%) and 364 (57.32\%) responded.

\section{- Place of access to contraceptive methods}

Public health centers were cited by respondents as places of access to contraceptive methods in $72.44 \%$ of cases, followed by the health center of the Burkinabe's family well-being's association (60.16\%), pharmacies (38.27\%) and associations (16.54\%).

\subsection{Practices about Contraception}

Respondents who had used at least one contraceptive method accounted for $61.42 \%$ and 240 respondents (38.74\%) were still using one at the time of the survey. The male condom was the most used (92.56\%), followed by pills used by

Table 1. Distribution of respondents by age at first sexual experience.

\begin{tabular}{ccc}
\hline Age (year) at the first experience of sex & Total & Percentage \\
\hline$<15$ & 44 & 9.42 \\
$15-19$ & 353 & 75.59 \\
$20-24$ & 62 & 13.28 \\
$>24$ & 8 & 1.71 \\
& & 100
\end{tabular}


Table 2. Distribution of respondents according to reported benefits on contraceptive methods $(\mathrm{n}=554)$.

\begin{tabular}{ccc}
\hline Reported benefits & Total & Percentage \\
\hline Eviction of unwanted pregnancies & 467 & 84.30 \\
Eviction of STIs/HIV & 162 & 29.24 \\
Spacing of births & 76 & 13.72 \\
Improved family well-being & 09 & 1.62 \\
\hline
\end{tabular}

*sexually transmitted infections/human immunodeficiency virus.

Table 3. Distribution of respondents according to their answers on the disadvantages of contraceptive methods $(\mathrm{n}=364)$.

\begin{tabular}{ccc}
\hline Disadvantages & Total & Percentage \\
\hline Sterility & 154 & 42.42 \\
Menstrual cycle disorder & 124 & 34.16 \\
Weight gain & 47 & 12.95 \\
Exposure to STIs & & 11.02 \\
Slow return to fertility & 40 & 6.06 \\
Other & 22 & 25.34 \\
\hline
\end{tabular}

${ }^{* *}$ sexually transmitted infections.

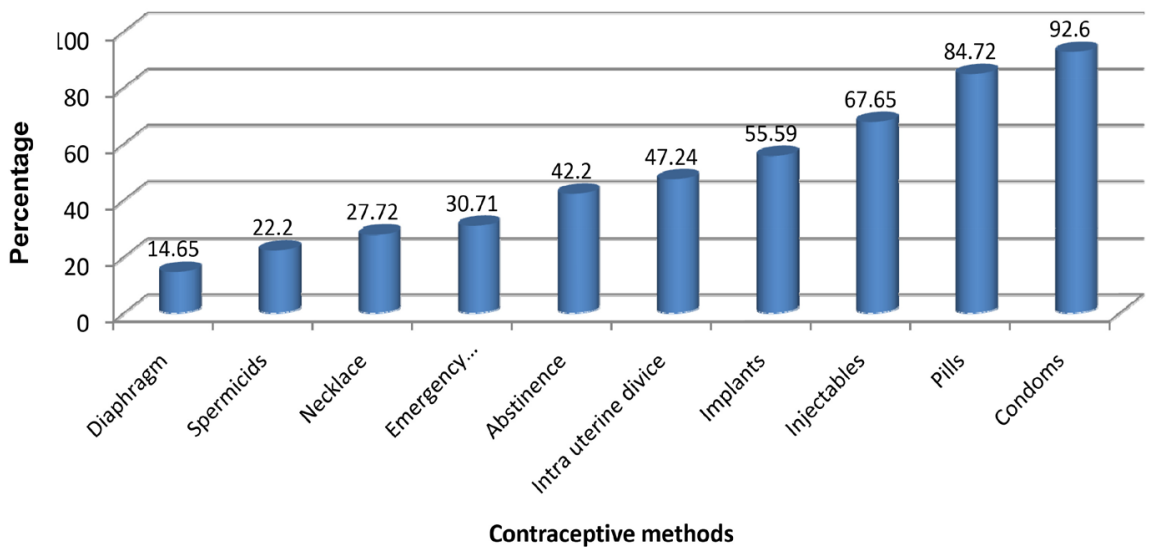

Figure 1. Distribution of respondents according to contraceptive methods they knew ( $\mathrm{n}=$ $635)$.

147 girls, i.e. $23.08 \%$ of the sample and $28.94 \%$ of the girls. As for the contraceptive methods already used, 390 respondents specified which methods they had used. The distribution of respondents according to the contraceptive methods used is reported in Table 4.

\subsection{Reasons for Not Using Contraceptive Methods}

The reasons that prevented the use of contraceptive methods according to 245 respondents are listed in Table 5 below. 
Table 4. Distribution of respondents according to contraceptive methods already use ( $\mathrm{n}=$ 390).

\begin{tabular}{ccc}
\hline Contraceptive methods already used & Total & Percentage \\
\hline Abstinence & 10 & 2.56 \\
Necklace & 1 & 0.26 \\
Emergency contraception & 33 & 8.46 \\
Diaphragm & 1 & 0.26 \\
Implants & 62 & 15.90 \\
Injectables & 72 & 18.46 \\
Pills & 90 & 23.08 \\
Condoms & 361 & 92.56 \\
Spermicids & 6 & 1.54 \\
Intra uterine device & 15 & 3.85 \\
\hline
\end{tabular}

Table 5. Distribution of respondents for reasons of non-use of contraceptive methods (n $=245)$.

\begin{tabular}{ccc}
\hline Reasons for not using contraceptive methods & Total & Percentage \\
\hline Not necessary & 74 & 30.20 \\
My parents do not want & 20 & 8.16 \\
My partner refuses & 15 & 6.12 \\
My religion forbid it & 24 & 9.80 \\
Methods not available & 3 & 1.22 \\
Methods inaccessible & 2 & 0.82 \\
No answer & 107 & 43.67 \\
\hline
\end{tabular}

\section{Discussion}

\subsection{Socio-Demographic Characteristics}

The survey was conducted at the youth listening center of Bobo-Dioulasso city and showed an average age of 20.62 years \pm 3.62 years. This result is close to those of Adohinzin [4] and Fourn [5] who, respectively, reported mean ages of 19 and 21 years.

The epidemiological profile of the respondents reveals that most of them were educated with a secondary level of $75.28 \%$ and a higher level of $22.99 \%$. As a result, the information conveyed about contraception in the general population reaches this target group, thus explaining the attendance of this center by these young people.

The age at first sexual intercourse in Burkina Faso is relatively early [6]; this is the case in our series where the average age at first intercourse was 18.42 years. This age at which young people engaged in their first sexual activity is also noted in 2003 Demographic and Health Survey (DHS), where more than half of girls 
aged 15 - 19 have ever had sex. Girls in our study were 16.72 years old when they got sex for the first time. According to the Demographic and Health Survey (DHS) 2010 the median age of women at first union was estimated at 17.8 years and almost a quarter of adolescent girls (24\%) already started sex and maintained it regularly.

\subsection{Knowledge about Contraception}

According to the 2003 DHS, 91\% of women and 93\% of men in Burkina Faso knew at least one contraceptive method. In our series, $98.12 \%$ of respondents knew or had already heard about contraceptive methods. This rate is higher than those of Faye (45.2\%) in Senegal [7], Simbar (55\%) in Iran [8] and Masmoudisoussi (87\%) in Tunisia [9]. In these countries, strong Islamic education would influence the level of knowledge about reproductive health.

In Burkina Faso, since the advent of the HIV/AIDS pandemic, extensive awareness campaigns have been undertaken on the condom that was at the center of prevention. Even young girls, during these campaigns, were trained to negotiate the use of the male condom while sex. This could justify the result in our study where condoms appeared to be the most popular contraceptive method (92.60\%). In addition, the 2010 DHS had already shown that the male condom was the best-known method by $93 \%$ in young populations.

The pill is the most popular modern contraceptive method for teenage girls and young women. It is available in pharmacies, maternal and child health centers and it has been subsidized by the Government to be cheaper. The distribution of pills in community by actors of Burkinabè's family well-being association could justify why pill are so known and used in its intervention areas. In our series, pills were the second most common contraceptive method among respondents (84.72\%). This result was also observed by Agbéré [10] and Banhoro [11] who reported respectively $63.6 \%$ and $80.6 \%$.

The level of knowledge of the contraceptive methods by the respondents was satisfactory because $76.9 \%$ were able to cite at least two advantages of the contraceptive methods. The benefits listed were "protection against unwanted pregnancy" and "protection against STIs and HIV/AIDS". These same advantages were found in the series of Nanema [12] and Cissé [13].

The school was the main source of information for the surveyed contraceptive methods in our study with a rate of $65.35 \%$, followed by peers $(17.32 \%)$ then health centers $(9.92 \%)$. Our results could be explained by the fact that the majority of the respondents had a high level of schooling. The school is, therefore, a privileged place for learning and acquiring knowledge about contraceptive methods. Indeed, the Life and Earth Sciences' curriculum, taught in high school and university, contributes to improving knowledge of pupils and students in reproductive health.

\subsection{Practices of Contraception}

According to the 2010 DHS, 50.5\% of Burkinabe's population who reached sec- 
ondary school or university level used at least one contraceptive method. In our study, 467 respondents have already had sex and $61.42 \%$ used at least one contraceptive method. Andonaba [14] and Camara [2] reported respectively 16.6\% and $59.3 \%$ in their series. According to respondents, condoms were the most frequently used method (92.56\%). This rate is higher than that of Nacanabo [3] in Ouagadougou which was $86.64 \%$. This high rate of condom use can be explained by its availability and low cost. Condom awareness should be continued for students as its benefits are sure and known. Pill was the second modern contraceptive method used by the respondents (23.08\%). This finding was noted by Rowen [15] in the USA and by Sorhaindo [16] in Jamaica. Unlike the condom, the use of pill requires the intervention of a health worker who will explain benefits and disadvantages so that the client can make an informed choice. As for emergency contraception, its utilization rate was low (8.46\%). Fourn [5], in Republic of Benin, noted $18 \%$ of this type of contraception. The reason for this low utilization rate was the lack of an adequate source of information and its high cost. Its use should be encouraged as it represents an alternative of illegal abortions.

\subsection{Obstacles to the Practice of Contraception}

The Demographic and Health Survey in Burkina Faso (DHS) 2010 identified side effects as one of the reasons given by non-users of family planning methods. Some authors also emphasize the repressive attitudes of some health care providers towards teeners, through a bad welcome and/or a value judgment made on them, which constitutes a brake on the use of contraceptive methods. A religious culture could also hinder the use of contraceptive methods, as is the case in our study, where $9.80 \%$ of respondents said they were prohibited by their religion. In 2013, a United Nations Fund for Population's study on sexual and reproductive health in Burkina Faso linked religion to the use of modern contraceptive methods. The high cost of some contraceptive methods, such as emergency contraception, has been cited by young people as one of the barriers to their use.

\subsection{Limitations of the Study}

In the conduct of our study, we were confronted with certain limitations and insufficiencies related to the transversal nature of the study. Since sex is a taboo subject in our societies, the majority of questions focused on sexual behavior which is intimate and sentimental. As a result, some questions did not have answers. Despite these limitations, our results appear important and have been discussed.

\section{Conclusion}

This study shows that respondents had a fairly satisfactory level of knowledge. But the rate of use of contraceptive methods remains low. For many reasons, 
young people still have risky behaviors, such as unprotected sex. Focus should be put on programs reinforcing the teaching of sexuality and contraception at schools, as well as educational programs or intervention in the community.

\section{Conflicts of Interest}

The authors declare no conflicts of interest regarding the publication of this paper.

\section{References}

[1] Planification Familiale (2014) La planification familiale: L'Afrique de l'ouest francophone en mouvement. Un appel à l'action, $28 \mathrm{p}$.

[2] Camara, F. (2017) Comportements sexuels à risque chez les adolescents de niveau collégial en Guinée: Exploration des facteurs personnels et interpersonnels associés. Mémoirede maitrise en santé communautaire-santé mondiale. 137 p.

[3] Nacanabo, R.N.P. (2007) Connaissances et pratiques de la contraception chez les adolescentes en milieu scolaire de la ville de Ouagadougou. Thèse med. Université de Ouagadougou. Unité de Formation et de Recherche en Science De la Santé, 69 p.

[4] Adohinzin, C.C.Y. (2016) Connaissances et pratiques contraceptives chez les jeunes burkinabè de 15 à 24 ans. Annales des sciences de la santé, 1, 35-59.

[5] Fourn, N., Aguemon, B., Kabibou, S., Hounkponou, F., Lafia, I. and Fourn, L. (2014) Connaissances, attitudes et pratiques de la contraception d'urgence chez les étudiantes à l'Université de Parakou (Bénin). Santé Publique, 26, 541. https://doi.org/10.3917/spub.144.0541

[6] Institut National de la Statistique et de la Démographie (INSD) et ICF International (2012) Enquête Démographique et de Santé et à Indicateurs Multiples du Burkina Faso 2010. INSD et ICF International, Calverton, MD, 525 p.

[7] Faye, M. (2004) Connaissances attitudes et pratiques en matière de santé de la reproduction des adolescentes du Centre de Dépistage Volontaire Anonyme et Gratuit (CDVAA) de Pikine-Guediawaye. Mémoire de Maitrise: Université Cheik AntaDiop de Dakar, Institut de Formation et de Recherche en Population, Développement et Santé de la Reproduction, 51 p.

[8] Simbar, M., Tehrani, F.R. and Hashemi, Z. (2005) Reproductive Health Knowledge, Attitudes and Practices of Iranian College Students. Eastern Mediterranean Health Journal, 11, 888-897.

[9] Masmoudi-Soussi, J., Bellaaj-Lachtar, F., Aloulou-Bouguecha, J., Amami, O., Halouani, A. and Jarraya, A. (2006) Vie sexuelle des adolescents (enquête auprès de 352 étudiants tunisiens). Annales Médico-psychologiques, revue psychiatrique, 164, 395-401. https://doi.org/10.1016/j.amp.2004.12.003

[10] Agberé, A.R.D., Tchagafou, M., Houedji, K., Baeta, S., Boukari, B., et al. (2003) Utilisation des méthodes contraceptives par les jeunes femmes de Lomé (Togo). Cahiers Santé, 13, 243-245.

[11] Banhoro, L. (2012) Connaissances, attitudes et pratiques de la contraception en milieu estudiantin des universités publiques de la ville de Ouagadougou (BURKINA FASO). Thèse Med. Université de Ouagadougou, Ouagadougou, 94.

[12] Nanéma, M. (2004) Les facteurs déterminants les comportements sexuels à risque des adolescents scolaires face au SIDA: Cas de quelques lycées et collèges (Ouagadougou) Mémoire de maîtrise présenté à l'unité de formation et de recherche en 
sciences humaines, $110 \mathrm{p}$.

[13] Cissé, Y.A. (2010) Connaissances attitudes et pratiques de la contraception en milieu scolaire dans la commune urbaine de GAO. Université de Bamako, Bamako, 90 p.

[14] Andonaba, J.B., Traoré, A., Barro, F., Niamba, P. and Traoré, B.A. (2005) Connaissances, attitudes et pratiques des jeunes du secondaire du district de Kaya en matière de sexualité et de contraception. Burkina Médical, 8, 71-78.

[15] Rowen, T.S., Smitha, J.F., Eisenberg, M.L., Breyer, B.N., Drey, E.A. and Shindel, A.W. (2011) Contraceptive Usage Patterns in North American Medical Students. Contraception, 83, 459-465. https://doi.org/10.1016/j.contraception.2010.09.011

[16] Sorhaindo, A., Becker, D., Fletcher, H. and Garcia, S.G. (2002) Emergency Contraception among University Students in Kingston, Jamaica: A Survey of Knowledge, Attitudes, and Practices. Contraception, 66, 261-268.

https://doi.org/10.1016/S0010-7824(02)00384-0 